Article

\title{
Trust and Sharing in Online Environments: A Comparative Study of Different Groups of Norwegian Car Sharers
}

\author{
Tom Erik Julsrud ${ }^{1, *(D)}$ and Tanu Priya Uteng ${ }^{2}$ (D) \\ 1 CICERO Center for International Climate Research, 0349 Oslo, Norway \\ 2 Institute of Transport Economics, 0349 Oslo, Norway; tanu.priyauteng@toi.no \\ * Correspondence: tom.julsrud@cicero.oslo.no
}

check for updates

Citation: Julsrud, T.E.; Priya Uteng, T. Trust and Sharing in Online Environments: A Comparative Study of Different Groups of Norwegian Car Sharers. Sustainability 2021, 13, 4170. https://doi.org/10.3390/su13084170

Academic Editors: Margareta Friman, Lars Olsson and Hugo Guyader

Received: 7 February 2021

Accepted: 3 April 2021

Published: 8 April 2021

Publisher's Note: MDPI stays neutral with regard to jurisdictional claims in published maps and institutional affiliations.

Copyright: (c) 2021 by the authors. Licensee MDPI, Basel, Switzerland. This article is an open access article distributed under the terms and conditions of the Creative Commons Attribution (CC BY) license (https:// creativecommons.org/licenses/by/ $4.0 /)$.

\begin{abstract}
Though multiple studies have explored the phenomenon of car sharing, very few have indulged into exploring how different forms of trust varies between users of different business models. We address this research gap through employing quantitative data analyses of car sharers in Norway. Results show that the levels of ingroup and outgroup-trust (i.e., trust towards friends/family or unfamiliar persons) are markedly low for the members of the peer-to-peer scheme $(\mathrm{M}=3.4 / 2.9)$ as compared to the cooperative $(M=6.0 / 4.8)$ and business-to-consumer scheme $(M=5.7 / 4.4)$. In contrast, technology-based trust is more important for the P2P sharers $(\mathrm{M}=5.8)$ than cooperative $(\mathrm{M}=5.6)$ and the $\mathrm{B} 2 \mathrm{C}$ users $(\mathrm{M}=5.6)$. Our findings echo previous studies, indicating that a different set of institutional logics is driving the transactions at the emerging P2P platforms compared to former non-profit sharing communities.
\end{abstract}

Keywords: car sharing; trust; peer-to-peer; institutional logic; collaborative consumption

\section{Introduction}

The organized variant of shared consumption is increasingly becoming prominent in future urban imageries, gaining traction in both research and policy-making fields. Based on experiences from the collaborative computing movement in the late 1990s, this "sharing turn" in the economy, whereby a number of digital applications have been introduced, has facilitated various forms of sharing, lending, bartering, or co-production [1,2]. New forms of collaborative consumption have emerged across different markets and in different forms. Evidences highlight that collaborative consumption holds potential to promote sustainable resource consumption and improve resource allocation [3,4]. In the field of transportation, digital infrastructure, mobile applications, and new business models have paved way for various de-privatized transport services, and car sharing holds a prominent place in this landscape. It is increasingly being seen as an emerging technological niche that can propel a shift towards more sustainable transport system [5-7].

While informal car sharing has been around as long as private cars ownership, formal car sharing is based on membership in an organization or web-platform where cars can be rented and operated on a self-access basis for short- and medium-term use [8]. It is rooted in the ethos that rather than owning a private car, need for car-based services can be met through membership of an organized platform, underlining a type of access-based consumption where consumers pay for using a vehicle instead of owning one (In this paper we use the term "car sharers" to refer to the individual users of a car sharing platforms, while "car sharing providers" is used for the enterprises promoting the services. For the P2P form, we have also used "peer-provider" and "consumer" for the partner involved in the transaction) [9]. Although it does not represent a radically new technology, car sharing challenges the foundations of the car-based mobility system which has been and is still dominated by private ownership [10,11].

In the early stages of car sharing in the Nordic countries, the system was often based on local initiatives. NGOs, local communities, or Cooperatives invested in a pool of cars 
that the members could use whenever needed. In Norway, as in most other Scandinavian countries, these initiatives often had an idealistic motivation to curb use of private cars by making it easier to live without buying one $[8,12,13]$. The largest cooperative car sharing system in Norway, "Bilkollektivet", has roots in the green movement, where car sharing was considered a way to sustainably develop cities and improve their ecological footprint and social belongingness.

Over the last decade, this type of service has been supplemented with a large number of business to consumer (B2C) car sharing services, where commercial actors rent vehicles out to a registered group of users. In many markets, traditional car dealers or car rental companies remain the key actors. More recently, peer-to-peer (P2P) type of car sharing has been introduced that is more closely aligned with the idea of collaborative consumption in different sectors. The P2P sharing systems grew out of open source movement where software engineers and millions of volunteers developed codes and solved problems collectively [14,15]. This global, web-based movement paved the way for other kinds of peer produced content free for sharing, such as Wikipedia and numerous file-sharing applications. Hence, there is a strong historical connection between the emergence of peer-to-peer platforms and the general idea that the new technology-enabled practices could empower people [16].

Following Frenken and Schor (2017), collaborative consumption is characterized by "underutilized privately owned resources that are made available to other parties for a limited time period and it is based on consumption of idle capacity" (Ibid, pp. 4-5). This definition suggests that P2P car sharing easily falls within the concept of collaborative consumption. P2P form of sharing may or may not be a recurring incidence and the users may be distributed over a wider geographical area than the users of the other types of car sharing.

Trust is crucial for successful sharing in online environments [2,17] and lack of trust has been described as a barrier for a wider diffusion of e-commerce and sharing applications [18-21]. In case of car sharing, the shared item is often of high value both from economic and safety perspectives, rendering lending and borrowing of private car difficult without firmly placing the element of 'trust'. Trust is a fundamental but complex phenomenon and different forms of trust are at play in social groups and societies. The question is if the new forms of sharing are based on the same forms of trust as the traditional sharing, or if there are other mechanisms at play which need further elaboration and eventual uptake in policy-making.

A growing body of literature has begun to explore the differences in consumer attitudes, motives and travel behavior related to different car sharing platforms. Differences between users of Coop and B2C car-sharing types relate to income, education, and patterns of use $[22,23]$ while different sets of attitudes and values have been found to motivate an interest in P2P schemes [24-27]. Although trust has been recognized as an essential element for car sharing, its variability among the "old" and "new" types of car sharing remains largely underexplored in literature [28,29].

This paper fills this gap by addressing the underlying trust building mechanisms for the different car sharing schemes. The study's context is well suited since all three variants of car sharing are currently being provided in Norway. The research question guiding this study is whether the emerging peer-to-peer (P2P) type of car sharing rests on other forms of trust than those guiding cooperative and market-based models? This question is of relevance since a successful deployment of car-sharing vis-à-vis urban mobility systems necessitates a better understanding of consumers' choice of different types of sharing models. This question also facilitates a broader discussion on how new business models, typical of the emerging sharing economy, may cause changes in everyday social interactions, cultures, and life in modern societies.

In the next section of this paper, we lay out the theoretical background for our analysis (Section 2) and in Section 3, we raise three hypotheses that will guide the later analysis. Next, we present the methodology along with the data material (Section 4). In the subse- 
quent section (Section 5), results from multivariate analyses are presented followed by a discussion of key results (Section 6). Key findings suggest that adhering to different sharing types is based on different types of trust and the Coop and P2P formats are supported by different trust constellations. The discussion presents some explanations and draws out implications for managing trust to support car sharing, as it can become one of the primary ways for transitioning to more sustainable mobility.

\section{Literature Review}

\subsection{Sharing and Trust}

Until recently, sharing, as opposed to purely economic transactions, was limited to ones trusted social network, which largely comprised family, friends, and neighbours. Sharing was primarily related to reciprocity and to a much lesser extent to monetary gains [15]. Recent advances in information and communication technology (ICT), particularly as they relate to smartphones and broadband connectivity have enabled sharing among a much broader set of agents, most notably strangers. Digital platforms have enabled sharing with strangers less risky and more appealing through sourcing information on users via the use of ratings and reputations [16,30-32].

Lawrence Lessig [33] underscores that while sharing has always existed, the fundamental change occurred when ICT enabled us to formalize and monetize the previously informal and voluntary elements. He describes this as a shift from "thick" to "thin" sharing, where the former refers to the form of sharing in which there is a mutual benefit for all parties engaged in the transaction, i.e., it is not a purely self-interested act. Such behavior is consistent with the sharing exhibited by member of a trusted or tightknit community. Thin sharing, on the other hand, is more focused on individual gain and resembles the self-interested actor model within classical economics, and in recent years, there has been a substantial increase in both the volume and variety of thin sharing. Following Lessig (ibid), a thin sharing economy is often easier to support (through regulatory mechanisms) than its thick sharing variant. The distinction between thin and thick sharing resembles to some extent the twin concepts of "sharing in" and "sharing out" as suggested by Tim Ingold (1986). While "sharing in" is the common consumption of resources within a denser circle of people regarding ownership as common, "sharing out" involves giving to those outside the social group boundaries [34]

From the point of view of neo-institutional theory, the difference between P2P based sharing and former types has been recognized as representing different social fields with different institutional logics [35-37]. A key premise within this branch of theories is that the actors are constrained by the same institutional set-up and adhere to a common "meaning system" or "belief system" and collectively, they represent a social field [38,39]. Institutional change is typically more easily accomplished in fields that are emerging as institutionalized practices and have not yet been established or stabilized [40]. Laurell et al. (2017) argue that the new sharing economy is riddled with tensions between the market and non-market logic of idealism and platform capitalism driven by for-profit firms.

Hence, based on different historical roots, there are reasons to assume that different types of car sharing platforms tend to adhere to different logics of sharing. While the older Cooperative form is based on a community-logic where norms of reciprocity and solidarity operate within a close social circle, business-to-consumer forms adhere to a market-based logic, characterized by distribution of goods based on price-mechanisms and non-personal relationships in a bounded market. Peer-to-peer sharing, however, belongs to a new type of organizational structure where goods are distributed equally across the members of a social network over digital networks [41-43]. These forms are market-based, since goods are shared for money in an open market, but at the same time there are elements of egalitarianism, moral commitment and reputation-mechanisms involved resembling a non-market logic $[3,44,45]$ Arguably, P2P sharing is based on a combination of both community and market-based logics. As argued by Belk (2014, p. 1597) “ ... collaborative consumption occupies a middle ground between sharing and marketplace exchange, with 
elements of both". The key features of P2P format qualify it to be a candidate for the network-based logic of sharing.

A much cited definition of trust describes it as a "... psychological state comprising the intention to accept vulnerability based upon positive expectations of the intention of or behaviour of another." ([46], p.395). Accordingly, trust represents a form of positive expectations in situations where it is difficult or impossible to take precautions. It is an important point that these "positive expectations", upon activation of trust, have no safe ground or guarantees, and as emphasized by Giddens [47], it always involves a "leap of faith". In tune with the conceptual framing of sharing in and sharing out, trust that is directed toward friends, families, and acquaintances has been called ingroup trust in contrast to the more outward directed outgroup trust that involves trusting strangers, people of another religion etc. Ingroup trust is usually a central element of the community-based logic. Outgroup trust operates within cultural regions and countries and is seen as a particularly important dimension of national economies, impacting how new innovations, events or social changes are handled [48-50]. Empirical studies have repeatedly documented significant variations in the level of outgroup trust across nations, generally explained by cultural differences [51,52]. Outgroup trust is therefore expected to be of particular relevance for economic systems and market exchanges.

Studies highlight that in P2P electronic communities, relational trust between buyers and sellers is important for customer satisfaction $[20,27,53]$. Having trust helps to overcome barriers related to engagements in collaborative consumption, and cultures where trust levels are high have natural benefits for adopting digital sharing. The argument is that people's trust can be transferred to sharing outside the realm of the local sphere $[27,54,55]$. This means that sharing in online environments seemingly operates with "thinner" trust rooted in technological opportunities and networked identities. Social interaction in networked environments can be forged quickly as swift trust based on clear role expectations and collective identities [56,57]. It has recently been suggested that applications based on block chain technologies can make the technological dimension of trust in online environments even more central in future [58-60]. Trust in P2P networks is therefore to a large extent technology-based trust (In the rest of this paper we use the term "techno trust" as a short form of technology-based trust), where positive expectations are based on functioning algorithm, infrastructures, and applications.

\subsection{Sharing, Trust, and Urban-Transport Planning}

Engineering sciences have traditionally dominated the transport field and provided rationales for increasing road capacities (for car driving) based on the so-called rational choice theory and arguments based on travel time minimization. However, Golightly et al. (2019) reinstated an emerging and increasingly accepted argument that travel choices do not conform to traditional models of rational analysis. "Instead, they are influenced (particularly in the case of single-occupancy vehicles and private ownership) by affective influences (i.e., influences on our mood and emotions), by logistics and flexibility and, in peer-to-peer travel sharing, factors of trust, and sharing of personal space." (ibid: 1). Both expectations and trust vary according to the different models of sharing, i.e., discrete (P2P module) versus ongoing use of services (Cooperative and B2C module). Plotting these differences is important as it has implications for both the design and use of technology, for patterns of trust-building, for concerns around remuneration and deployment of business models which can assure a continued growth of car sharing [61,62]. On-demand and isolated event services like the P2P car sharing module typically rely on mobile devices and offer little opportunity to establish trust in the traditional style. Instead, it tends to rely on (digital) reputation mechanisms in addition to the technologies and software. Therefore, dynamic systems have been historically problematic for peer-to-peer sharing arrangements and are more viable when mediated through a reputable organization (e.g., a third party such as Zipcar) (Golightly et al., 2019, [28]). 
In a study on human factors and shared use in the UK Transport system, Golightly et al. (2019, [49]) found only modest growth potentials in the peer-to-peer services. They highlight that "The advance of ICT in this area has not seen substantial gain, and there are still more fundamental questions of trust, coordination and social effort, and perceived risk required to form new sharing relationships, particularly for travel that involves both nuanced activities and a need to share space. Social groups cannot be artificially constructed, but where there are existing social groups, there is some opportunity for growth, although this needs policy support for ongoing support and coordination" (ibid).

Further, studies have found that systems of regulation and governance can be important to build trust in digital environments and overcome situations where self-interest act as barrier to collaboration [63]. Hence, development of reliable institutions and technological systems are good options to support P2P form of sharing. In a study on trust in the urban planning domain, Krawchenko [64] concludes that a useful tool for cities would be to regularly evaluate and report on key indicators and trends. These indicators and trends need to be open to adjustment and improvement along the way, and residents and businesses should be part of this process.

\section{Hypotheses}

The theoretical section suggests that the older, community-based sharing systems like Coop are likely to rely more on ingroup trust, while outgroup trust may have a more central position in the B2B car sharing systems founded on market-based logics. In the newer P2P car sharing system, however, we may assume that a network-based logic is more dominant leading to a stronger technological based trust, as well as outgroup trust. Based on the discussion above we can formulate three hypotheses that will guide the forthcoming analysis:

Hypothesis 1 (H1). Ingroup trust will be more important for community-based car sharers.

Hypothesis 2 (H2). Outgroup trust will be more important for the B2C and P2P car sharers.

Hypothesis 3 (H3). Techno trust will be most important for the P2P car sharers.

\section{Data and Methodology}

In this paper, we focus on the three largest car sharing providers in NorwayBilkollektivet (In Norwegian; "The Car Collective”) (Coop), Hertz (B2C) and Nabobil (In Norwegian; "The neighbour's car") (P2P). Bilkollektivet is a Cooperative car sharing scheme that was established in the mid-1990s in Oslo and later branched out to other Norwegian cities. Bilkollektivet was initially founded by a grass-root organization that considered car sharing as a way to support greener lifestyles. However, at the turn of the millennium, a number of for-profit car sharing companies were established. One of the crucial players today is Hertz bilpool which has procured other B2C enterprises. The company currently has a fleet of over 150 vehicles, most of which are located in the Oslo metropolitan area, but also available in other Norwegian cities. In 2015, Nabobil entered the market as the first P2P car sharing company in Norway. This service facilitates members who are seeking to rent vehicles for private use as well as members who are planning to rent out their car. The transactions between renters and peer-provider are coordinated by an operator that has an inbuilt insurance service minimizing the riskP2F. Currently Nabobil has more than about 170,000 registered users and 5500 vehicles in over 200 municipalities spread throughout Norway. In terms of users and vehicles, Nabobil is significantly larger than the entire non-P2P Norwegian car sharing sector. However, as many of the users in this scheme are passive members primarily renting out their cars, a direct comparison between these schemes is difficult [65].

Data used in this study was collected through an online questionnaire distributed among users of different car sharing platforms in Norway's four biggest citiesP4F Approximately 70 percent were in the larger Oslo region; 30 percent in Bergen, Trondheim, and 
Stavanger. The differences reflect the actual difference in the uptake of car sharing in these cities. The response rate recorded per scheme is as following:

The survey was distributed by the car sharing operators that were participants in a heterogenous group of stakeholders who were invited to participate in workshops and meetings as part of the research project this work comes out of. (The members of the stakeholder group did not influence the project analyses in any way). The operators did not wish to reveal how many members received the questionnaire, but since we know the total number of members in the three schemes, we have a rough estimate of the response rate. As indicated in Table 1, response rate remains lowest for Nabobil (P2P), only one per cent. Car sharers distributed information to their members through e-mails and on their websites and as an incentive for participating respondents could enter a raffle with the opportunity to win NOK 500 (approx. €50). In Bilkollektivet (Coop), the response rate was estimated to be 16 per cent and 4 percent for Hertz (B2C). The survey was distributed in November-December 2017 and collected information on travel behavior, preferences, life circumstances, personality related questions, and levels of trust. Measures of ingroup and outgroup trust were based on standardized items as applied in the World Value Surveys [66]. Questions pertaining to trust addressed levels of trust for family, neighbours, and acquaintances (ingroup) and for people one meets for the first time and people belonging to another religion (outgroup). Although trust in technology has been much discussed in the literature, the bulk of studies are of a theoretical or qualitative type [58,67], or they address particular technologies or social contexts [68-70]. In this study, we focus on a more generic form of trust in new technologies where, to the best knowledge of the authors, no standardized scale exists. As an indicator for techno trust, we use three items addressing belief in technologies and its potential for improvement of life quality (e.g., "I welcome all new technological innovations"). All measures relied on the use of a 7-points Likert scale. As an indicator of technological confidence, we used frequency of use of various digital sharing applications (see Table 2). We also included the following control variables: gender, age, and education. Table 3 highlights the measures that had an acceptable scale reliability, although the techno trust value was low (Cronbach alpha scale $=0.568)$. This suggests that the latter scale should be treated with caution. However, although low score are not optimal, scores on the level of 0.05 are considered acceptable in exploratory studies [71]. The Cronbach Alpha is sensitive for number of items and with short scales (e.g., scales with less than 5 items) it is common to find quite low Cronbach values. Additionally, Briggs and Cheek (1986) have argued that an alternative to CA for scale with few items may be the mean inter-item correlation. In this case this value is 0.297 which is within the range suggested by these authors (between 0.2 to 0.4 ) [72]. All measures can be found in the Appendix A.

Table 1. Response rate for the survey with members of car sharing schemes $(\mathrm{N}=3130)$.

\begin{tabular}{ccccc}
\hline CS Scheme & Type & Total No. of Members & Responses Received & Response Rate (\%) \\
\hline Nabobil & P2P & 130,000 & 1737 & 1 \\
Bilkollektivet & Coop & 7000 & 1119 & 16 \\
Hertz & B2C & 6684 & 274 & 4 \\
\hline
\end{tabular}

Table 2. Use of sharing applications on the Internet in the last 12 months and car sharing type. Percent.

\begin{tabular}{ccccc}
\hline & P2P & Coop & B2C & Total \\
\hline Selling, buying, or giving away used items (eBay, etc) & 86 & 81 & 81 & 84 \\
Short time renting of tools or items (Peerby, etc) & 9 & 5 & 7 & 8 \\
Buying excess food (too good to go, etc) & 21 & 16 & 19 & 19 \\
Short term accommodation (AirbBNB etc) & 43 & 43 & 35 & 43 \\
Ordering of short-term services & 20 & 16 & 16 & 18 \\
Never used & 8 & 13 & 15 & 10 \\
\hline
\end{tabular}


Table 3. Reliability tests and descriptive statistics for reflective measures.

\begin{tabular}{ccccc}
\hline & \# of Items in Scale & Cronbach's Alpha & St. Dev & Kurtosis \\
\hline Ingroup trust & 3 & 0.923 & 1.377 & -1.252 \\
Outgroup trust & 3 & 0.918 & 1.17 & -0.193 \\
Techno trust & 3 & 0.568 & 0.91 & 3.8 \\
\hline
\end{tabular}

\section{Results}

Table 4 shows key characteristics of the sample, differentiating between the three car-sharing schemes: “Nabobil" (P2P), "Bilkollektivet" (Coop) and "Hertz Carpool" (B2C). The sample consists of a majority of males, applicable to all three schemes. The dominance of male members has been found in earlier studies as well [22]. Further, most members use car sharing infrequently, with only $5 \%$ using it on a weekly basis. Coop members are the most active users, have a high proportion of employed users and the smallest proportion of students. P2P users use the cars over a wider geographical area than members of the other two schemes.

Table 4. Descriptive statistics for category measures and car sharing type. Percent.

\begin{tabular}{|c|c|c|c|c|}
\hline & $\mathbf{P} 2 \mathbf{P}$ & Coop & B2C & Total \\
\hline \multicolumn{5}{|l|}{ Gender *** } \\
\hline Female & 31 & 41 & 24 & 34 \\
\hline \multirow[t]{2}{*}{ Male } & 69 & 59 & 76 & 66 \\
\hline & 100 & 100 & 100 & 100 \\
\hline \multicolumn{5}{|l|}{ Social status ${ }^{* * *}$} \\
\hline Employed & 81 & 87 & 91 & 84 \\
\hline Part time employed & 6 & 6 & 2 & 6 \\
\hline Student & 7 & 2 & 5 & 5 \\
\hline \multirow[t]{2}{*}{ Other } & 7 & 5 & 3 & 6 \\
\hline & 100 & 100 & 100 & 100 \\
\hline \multicolumn{5}{|l|}{ Car sharing use ${ }^{* * *}$} \\
\hline Weekly & 1 & 5 & 3 & 3 \\
\hline Monthly & 5 & 37 & 23 & 23 \\
\hline Every 2nd month & 31 & 37 & 33 & 34 \\
\hline \multirow[t]{2}{*}{ Less often } & 63 & 21 & 41 & 40 \\
\hline & 100 & 100 & 100 & 100 \\
\hline \multicolumn{5}{|l|}{ Distance last trip ** } \\
\hline $0-20 \mathrm{~km}$ & 9 & 27 & 22 & 22 \\
\hline $21-60 \mathrm{~km}$ & 17 & 27 & 34 & 25 \\
\hline 61-100 km & 9 & 11 & 11 & 10 \\
\hline \multirow[t]{2}{*}{$101 \mathrm{~km}$ and more } & 64 & 35 & 32 & 42 \\
\hline & 100 & 100 & 100 & 100 \\
\hline
\end{tabular}

ANOVA sig ${ }^{* *} p<0.01 ; * * * p<0.001$.

A majority of car sharers have also been involved in other types of sharing. Only one in ten had never shared, borrowed, or lent out anything on digital platforms. As shown in Table 2, use of digital market applications, such as eBay was most widely used, followed by short time accommodation like AirBNB. Interestingly, the P2P car sharers were significantly more active sharers than users of the other schemes.

As indicated in Table 5, the concepts of outgroup and ingroup trust are positively correlated, but the same is not true for technology-based trust.

Table 5. Descriptive statistics and bivariate correlations between key concepts. Range: 1-7.

\begin{tabular}{cccccc}
\hline Variable & $\mathbf{M}$ & SD & Ingroup Trust & Outgroup Trust & Techno Trust \\
\hline Ingroup trust & 4.57 & 1.38 & 1 & - & - \\
Outgroup trust & 3.72 & 1.17 & $0.831^{* *}$ & 1 & - \\
Techno trust & 5.70 & 0.91 & 0.024 & 0.027 & 1 \\
\hline$* * p<0.01$
\end{tabular}

** $p<0.01$. 
To further understand the connections between the car sharing schemes and trust forms, a binary logistic regression analysis was conducted. The regression analysis, presented in Table 6, shows that the trust measures have a significant but different impact on choice of car sharing schemes, controlling for age, education, and gender. As demonstrated in the first model, both in- and outgroup trust negatively influence the use of P2P -sharing while high level of Techno trust, in contrast, significantly increase the likeliness of choosing this scheme. The second model shows that the Coop users display an opposite pattern; influenced positively by both in- and outgroup trust, and negatively by Techno trust. The third model shows that ingroup trust had a positive effect on B2C uptake, yet to a lower extent than Coop, and that people in this group tended to have lower education. This scheme was also more preferred by male drivers.

Table 6. Binary logistic regression analysis for car sharing schemes $(\mathrm{N}=3130)(1=$ Use of scheme last 12 months).

\begin{tabular}{|c|c|c|c|c|c|c|}
\hline & \multicolumn{2}{|c|}{$\mathbf{P} 2 \mathbf{P}$} & \multicolumn{2}{|c|}{ COOP } & \multicolumn{2}{|c|}{ B2C } \\
\hline & $\beta$ & Sig. & $\beta$ & Sig. & $\beta$ & Sig \\
\hline Ingroup trust & -18.033 & 0.000 & 7.371 & 0.000 & 4.194 & 0.000 \\
\hline Outgroup trust & -4.137 & 0.000 & 1.707 & 0.000 & -0.269 & 0.439 \\
\hline Techno trust & 0.697 & 0.000 & -0.404 & 0.000 & -0.063 & 0.402 \\
\hline Gender (Male) & -0.352 & 0.136 & -0.293 & 0.136 & 0.783 & 0.000 \\
\hline Age & 0.013 & 0.167 & 0.005 & 0.167 & -0.02 & 0.001 \\
\hline Education & -0.106 & 0.454 & 0.384 & 0.454 & -0.312 & 0.000 \\
\hline Constant & 27.932 & 0.000 & -13.083 & 0.000 & -7.764 & 0.000 \\
\hline \multicolumn{7}{|l|}{ Model summary: } \\
\hline$-2 \mathrm{LL}$ & 628.025 & & 1773.851 & & 1578.731 & \\
\hline Nagelk. $\mathrm{R}^{2}$ & 0.925 & & 0.716 & & 0.191 & \\
\hline
\end{tabular}

In summary, results indicate that high levels of in- and outgroup trust remain strong predictors for use of traditional cooperative car sharing. In striking contrast, P2P scheme, typically recognized as the corner stone of collaborative consumption, was preferred by drivers with lower levels of trust towards both people within the closer social circles of friends and family, as well as towards strangers in the wider social circles. The fact that P2P car sharing is attractive to people with lower level of in- and outgroup trust suggests that there are other mechanisms at play when social interaction and sharing of cars is undertaken in a network- and technology-based sharing format. The B2C type displays a middle position where ingroup trust has an impact, but outgroup and technology-based trust do not seem to have significant impacts.

\section{Discussion and Conclusions}

Based on the results above, the issue of whether the emerging peer-to-peer (P2P) type of car sharing rests on other forms of trust, than those guiding cooperative and market-based models, has been confirmed. The results support the first hypothesis, that Community-based car sharing, to a stronger degree, relies on ingroup trust, and the third hypothesis that $\mathrm{P} 2 \mathrm{P}$ based sharing, to a higher degree, is based on a technological based trust (techno-trust). However, the second hypothesis, that B2C and P2P car sharing to a higher degree rely on outgroup trust, was not supported. The former bore semblance to the Coop sharing form with a stronger connection to ingroup trust than outgroup. One explanation could be that this scheme was originally rooted in a former cooperative sharing scheme that was bought by Hertz. Additionally, this scheme is likely to be backed by trust in institutions, a concept that was not included in the original survey.

\subsection{Tentative Explanations}

An intriguing question is why we find such strong variations in trust forms between the older and newer types of car sharing. A salient reason for high in- and outgroup trust 
among Coop users could simply be that this car sharing type is attracting people who, in general, are trustful of others. As mentioned before, Coop emerged from the green movement of the 1990s and consequently, people sharing similar identities and opinions are attracted to this scheme. It is possible that image of the enterprise itself may be attracting a particular group of people that share much of the same beliefs and meaning, adhering to the same type of institutional logics of sharing. Given that this group of car sharers live primarily in households with young children might perhaps also be a reason for being more family oriented and trustful as compared to the P2P users. Studies have, on the other hand, given evidence of that P2P users are mainly driven by self-centered and utilitarian motives, rather than social or environmental ones [24,25,27,73]. Although no generational factor seems to be involved, different lifestyles might be contributing towards the differences noted in this study.

Additionally, the actual use of cooperative car sharing schemes might be further cementing stronger trust, given a higher level of familiarity with people in the community the member belongs to. As demonstrated in earlier research, repeated successful interaction with the same people over time is likely to build up trust [74,75]. Engagement in sharing activities is sometimes associated with altruistic and social values beneficial for the larger society, and social engagement is further seen as an enabler for building and solidifying trust $[44,76]$. This is akin to the principle of reciprocity present in denser social network, that over time generates cohesiveness and social trust [77]. In contrast, P2P is based on occasional exchanges reaching far beyond an individual's private social network. It is only occasionally that car sharing through this scheme involves people who know each other or have anything in common than an exclusive interest in sharing cars. Hence, the nature of the interaction does not automatically support building and sustaining of mutual trust.

It is clear that different formats of car sharing require different forms of trust to operate. In the Cooperative form, members pay a standard membership fee and have "stakes" in the enterprise, something that builds on a stronger form of trust. Membership, thus, presupposes some trust in the community. P2P, on other hand, is based on interactions where strong relational trust to the other users is less relevant for the members. This does not mean that trust altogether is irrelevant, but that other aspects may be more significant such as trust and confidence in the effectiveness of online reputation systems, reliance on social identity markers, system providers, insurance systems, etc. Studies highlight that (technology based) reputation system is crucial for consumer to establish trust in online-environments $[19,31]$. The active use of other sharing applications among the P2P car sharers suggests that experience and skills to use digital technology is crucial.

\subsection{Theoretical and Empirical Contribution}

The empirical findings presented in this study add to the body of knowledge on emergence of different car-sharing platforms, variations between some different sociodemographic indicators, user behavior, preferences, and motivations related to car sharing. Previous studies found differences between users of Coop and B2C car-sharing related to income, education, and patterns of use and different attitudes, whereas values have been found to motivate an interest in P2P schemes [22,24-26]. This study demonstrates that a significant variation in trust exists as well across the different car sharing schemes.

Our findings echo previous studies indicating that a different set of institutional logics is taking hold as sharing shifts to digital platforms, gradually moving away from non-profit communities [35,37] As recently argued by Grahbner and König [43], sharing economy appears to be transcending both pre-industrial communities and traditional market coordination. Driven foremost by development of ICT, new forms of socio-economic coordination have emerged. Although this study could not provide extensive information about the norms, values and meanings guiding the members of different sharing organizations, it demonstrated that peer-to-peer sharing draws on different forms of trust. We should note, however, that even though we draw connections between institutional logics and sharing schemes, studies suggest that multiple logics are often at play when people move between 
different social situations [78]. It is therefore likely that users of the three car sharing schemes discussed here may adhere to different sets of logic with different types of trust, changing over time and context of use.

Results further suggest that P2P sharing is not an extension of older types of sharing, but a new form based on "network-based logic" where the risk is mitigated by reliance on technology rather than strong ties in cohesive communities. As argued by Belk (2014), Bardhi and Echardt (2012), and others, the inherent logic might bear strong similarities to the logics guiding economic transactions which are dominated by rational trust. Our findings are adjacent to the arguments that new technologies, in combination with a shrinking trust in institutions, are triggering an upscaling of "distributed" trust that flows vertically between people and digital platforms $[17,58,79]$. Key elements to build up trust here are technological affordances provided by advanced algorithms, safe economic transaction systems and well-functioning reputation mechanisms where transactions and actors are evaluated for each sharing session. Our results here add to the body of work indicating that young people have more confidence in technology-players like Google and Facebook. This again suggests that there might be a new generation of P2P-users that adhere to another type of "sharing logic" [70].

Following this line of thinking, trust is redistributed from people to technologies. However, it could also be that the new network-based sharing is founded on a lighter and "swifter trust" than what is captured in the concepts of in- and outgroup trust. The term swift trust refers to trust that is quickly established for a limited period of time before it fades away, and studies on network-based collaboration have suggested that shared identities and role descriptions can be important to establish swift trust in networked environments [56,57]. Hence, it seems that a thinner form of trust is at play within peer-topeer network sharing that is hard to capture through old concepts.

\subsection{Implications}

This study suggests that a high level of general trust in others, as is the case for Norway and the other Nordic countries [80], is of little value for further development of the P2P car sharing variant. It is more likely that growth in this type of sharing scheme will be based on the functioning of trust in the digital network algorithms, reputation-based mechanisms, and strong institutions. Given that car sharing is an emerging phenomenon and still not one of the mainstream modes guiding daily travel behavior in the Norwegian urban areas, we further emphasize the need to take the local conditions of trust into account. To date, the Norwegian municipalities have shied away from conducting open, transparent, and meaningful public engagement on car sharing. Car sharing has primarily emerged as an independent initiative which, in parlance of business development stages, is still at a 'niche' stage. As a new and more sustainable way of travel in urban regions, it is still a relatively immature social practice compared to private ownership [13]. However, as digitalization and technological interfaces gain prominence in urban and transport planning practices (cf. smart cities and smart mobilities), it is important to engage different sub-sets of urban population on an ongoing basis. Further, through adopting an indicator-based approach, Norwegian municipalities can both address and manage the growth of car sharing through plotting key indicators affecting the uptake of the different business models of car sharing. A closer monitoring of car sharing systems could support development of sustainable urban environments, and studies have found that this kind of regulation is likely to be welcomed by the public [63]. Establishing monitoring systems would be an important step forward and will provide a suitable platform to address human factors like trust which are not easily captured in business or technical indicators.

\subsection{Next Steps}

This study is among the first to investigate how various forms of trust are related to car sharing platforms, and the variations documented here suggest that further studies are needed. Even though Norway scores high on generalized trust levels, we found that 
discrepancies exist between the members of P2P and Coop/B2C. It seems that trust is being interpreted differently in different domains. For example, car sharing in Norway is being envisioned as a set of standard protocols which should be tied to an organization, and organizational trust rather than personal trust. Personal trust, in the case of P2P members, is being replaced by technology-based trust and might be leaning heavily towards assessment of web-based reputation mechanisms. Other risk-reducing mechanisms, related to institutional trust and forging of "swift trust" between users based on shared identities or cultures, should also be further explored as explanations for sharing in P2P online groups.

It is interesting to note that Coop users are actively using car sharing while many P2P are only passive participants. While the community-based sharing forms have had strong positive symbolic value for an older generation, this may not to be the case for the new generation of P2P sharers. Thus, differences in underlying trust structures might be related to shifts in lifestyles. It is also vital to further probe to what extent does spatial location and easy accessibility to facilities on foot, bicycle, and public transport in daily lives, play a role in this contrasting set of values contra lifestyle. This study suggests that P2P members use the shared cars on distant trips than the users of other two schemes whose trips are more local, and thus of relatively short trip length.

Given that embedded group-based trust is not needed to spur growth in P2P services, as long as other preconditions are established, the mechanisms and dynamics behind the new and emerging forms of trust and engagement in digital sharing deserves to be further explored based on a judicious mix of qualitative and quantitative methods. Our limited focus on three types of trust needs to be bolstered through studies on other forms of trust.

Author Contributions: Conceptualization, T.E.J. and T.P.U.; Data curation, T.E.J.; Formal analysis, T.E.J. and T.P.U.; Investigation, T.E.J. and T.P.U.; Methodology, T.E.J.; Writing-original draft, T.E.J. and T.P.U. All authors have read and agreed to the published version of the manuscript.

Funding: Norges Forskningsråd: 267442; Norges Forskningsråd: 255430; Norges Forskningsråd: 283331; Norges Forskningsråd.

Informed Consent Statement: Informed consent was obtained from all subjects involved in the study.

Data Availability Statement: The data is not publicly available due to legal contracts with the Norwegian Center for Research Data (NSD).

Conflicts of Interest: The authors declare no conflict of interest.

\section{Appendix A}

\section{Survey Measures}

Ingroup trust

$\overline{\text { To what extent }}$ would you say that you trust the following people? (Scale 1-7)

- Person in your family.

- Neighbors.

- People that you know personally.

Outgroup trust

To what extent would you say that you trust the following people? (Scale 1-7)

- People you meet for the first time.

- People with another religion.

- People with another nationality.

Techno trust

To what extent do you agree or disagree with the following statements? (Scale 1-7)

- I welcome all new technological innovations.

- Computers and other modern technologies are frightening to me.

- Technologies will help us develop urban areas with better quality of life. 


\section{References}

1. Belk, R. You are what you can access: Sharing and collaborative consumption online. J. Bus. Res. 2014, 67, 1595-1600. [CrossRef]

2. Botsman, R.; Rogers, R. What's Mine is Yours. How Collaborative Consumption Is Changing the Way We Live; Collins: London, UK, 2011.

3. Hamari, J.; Ukkonen, A. The Sharing Economy: Why People Participate in Collaborative Consumption. SSRN Electron. J. 2013, 67, 2047-2059. [CrossRef]

4. Cheyne, C.; Imran, M. Shared transport: Reducing energy demand and enhancing transport options for residents of small towns. Energy Res. Soc. Sci. 2016, 18, 139-150. [CrossRef]

5. Chen, T.D.; Kockelman, K.M. Car sharing's life-cycle impact on energy use and greenhouse gas emissions. Transportation Research Part D. Transp. Environ. 2016, 47, 276-284.

6. Shaheen, S.A.; Mallery, M.A.; Kingsley, K.J. Personal vehicle sharing services in North America. Res. Transp. Bus. Manag. 2012, 3, 71-81. [CrossRef]

7. Martin, E.; Shaheen, S. The Impact of Carsharing on Household Vehicle Ownership. Access Mag. 2011, 38 , 23-38.

8. Truffer, B. User-led Innovation Processes: The Development of Professional Car Sharing by Environmentally Concerned Citizens. Innov. Eur. J. Soc. Sci. Res. 2003, 16, 139-154. [CrossRef]

9. Bardhi, F.; Eckhardt, G.M. Access-Based Consumption: The Case of Car Sharing: Table 1. J. Consum. Res. 2012, 39, 881-898. [CrossRef]

10. Urry, J. Mobilities; Polity: Cambridge, UK, 2007.

11. Marletto, G. Car and the city: Socio-technical transition pathways to 2030. Technol. Forecast. Soc. Chang. 2014, 87, 164-178. [CrossRef]

12. George, C.; Julsrud, T.E. The Development of Organised car Sharing in Norway: 1995-2018; Institute of Transport Economics: Oslo, Norway, 2018.

13. Julsrud, T.E.; Farstad, E. Car sharing and transformations in households travel patterns: Insights from emerging proto-practices in Norway. Energy Res. Soc. Sci. 2020, 66, 101497. [CrossRef]

14. Benkler, Y. Sharing nicely. On shareable goodsand the emergence of sharing as a modality of economic production. Yale Law J. 2004, 114, 273-358. [CrossRef]

15. Belk, R. Sharing. J. Consum. Res. 2010, 36, 715-734. [CrossRef]

16. Frenken, K.; Schor, J. Putting the sharing economy into perspective. Environ. Innov. Soc. Transitions 2017, 23, 3-10. [CrossRef]

17. Hawlitschek, F.; Teubner, T.; Weinhardt, C. Trust in the Sharing Economy. Die Unternehm. 2016, 70, 26-44. [CrossRef]

18. Mittendorf, C. Collaborative consumption: The role of familiarity and trust among Milennials. J. Consum. Mark. 2018, 35, 377-391. [CrossRef]

19. Gao, S.; Jing, J.; Guo, H. The Role of Trust with Car-Sharing Services in the Sharing Economy in China: From the Consumers' Perspective. In International Conference on Cross-Cultural Design; Springer: Berlin/Heidelberg, Germany, 2017.

20. Albinsson, P.A.; Perera, B.Y.; Nafees, L.; Burman, B. Collaborative Consumption Usage in the US and India: An Exploratory Study. J. Mark. Theory Pract. 2019, 27, 390-412. [CrossRef]

21. Tussyadiah, I.P. An Exploratory Study on Drivers and Deterrents of Collaborative Consumption in Travel. In Information and Communication Technologies in Tourism 2015; Tussyadiah, I., Inversini, A., Eds.; Springer: Berlin/Heidelberg, Germany, 2015.

22. Münzel, K.; Piscicelli, L.; Boon, W.; Frenken, K. Different business models-Different users? Uncovering the motives and characteristics of business-to-consumer and peer-to-peer carsharing adopters in The Netherlands. Transp. Res. Part D Transp. Environ. 2019, 73, 276-306. [CrossRef]

23. Prieto, M.; Baltas, G.; Stan, V. Car sharing adoption intention in urban areas: What are the key sociodemographic drivers? Transp. Res. Part A Policy Pract. 2017, 101, 218-227. [CrossRef]

24. Ballús-Armet, I.; Shaheen, S.A.; Clonts, K.; Weinzimmer, D. Peer-to-Peer Carsharing. Exploring Perception and Market Characteristics in The San Fransisco Bay Area, California. Transp. Res. Rec. 2014, 2416, 27-36. [CrossRef]

25. Wilhelms, M.-P.; Henkel, S.; Falk, T. To earn is not enough: A means-end analysis to uncover peer-providers' participation motives in peer-to-peer carsharing. Technol. Forecast. Soc. Chang. 2017, 125, 38-47. [CrossRef]

26. Schaefers, T. Exploring carsharing usage motives: A hierarchical means-end chain analysis. Transp. Res. Part A Policy Pract. 2013, 47, 69-77. [CrossRef]

27. Möhlmann, M. Collaborative consumption: Determinants of satisfaction and the likehood of using a sharing economy option again. J. Cons. Beh. 2015, 14, 193-207. [CrossRef]

28. Hawlitschek, F.; Teubner, T.; Gimpel, H. Consumer motives for peer-to-peer sharing. J. Clean. Prod. 2018, 204, 144-157. [CrossRef]

29. Ter Huurne, M.; Ronteltap, A.; Corten, R.; Buskens, V. Antecedents of trust in the sharing economy: A systematic review. J. Cons. Beh. 2017, 16, 485-498. [CrossRef]

30. Schor, J. Debating the sharing economy. J. Self-Gov. Manag. Econ. 2016, 4, 69.

31. Ter Huurne, M.; Ronteltap, A.; Guo, C.; Corten, R.; Buskens, V. Reputation Effects in Socially Driven Sharing Economy Transactions. Sustainability 2018, 10, 2674. [CrossRef]

32. Kim, S.; Yoon, Y. Recommendation system for sharing economy based on multidimensional trust model. Multimed. Tools Appl. 2014, 75, 15297-15310. [CrossRef]

33. Lessig, L. Remix: Making Art and Commerce Thrive in the Hybrid Economy; Penguin: London, UK, 2008. 
34. Ingold, T. The Appropriation of Nature. Essays on Human Ecology and Social Relations; Manchester University Press: Manchester, UK, 1986.

35. Laurell, C.; Sandström, C. The sharing economy in social media: Analyzing tensions between market and non-market logics. Technol. Forecast. Soc. Chang. 2017, 125, 58-65. [CrossRef]

36. Meir, J.; Reischauer, G. Capturing the dynamics of the sharing economy: Institutional research on the plural forms and practices of sharing economy organizations. Technol. Forecast. Soc. Chang. 2017, 125, 11-20. [CrossRef]

37. Cockayne, D.G. Sharing and neoliberal discourse: The economic function of sharing in the digital on-demand economy. Geoforum 2016, 77, 73-82. [CrossRef]

38. DiMaggio, P.J.; Powell, W.W. The Iron Cage Revisited: Institutional Isomorphism and Collective Rationality in Organizational Fields. Am. Sociol. Rev. 1983, 48, 147. [CrossRef]

39. Scott, W.R. Institutions and Organizations: Ideas, Interests and Identities; Sage Publications: Los Angeles, CA, USA, 2014.

40. Fligstein, N. Social Skill and Institutional Theory. Am. Behav. Sci. 1997, 40, 397-405. [CrossRef]

41. Kling, R.; Castells, M. The Internet Galaxy: Reflections on the Internet, Business, and Society; Oxford University Press: Oxford, UK, 2002.

42. Wellman, B.; Carrington, P.J.; Hall, A. Networks as personal communities. In Social Structures: A Network Approach; Wellman, B., Berkowitz, S.D., Eds.; Cambridge University Press: Cambridge, UK, 1988; pp. 130-184.

43. Grabher, G.; König, J. Disruption, embedded. A Polanyian framing of the platform economy. Sociologica 2020, 14, 95-118.

44. Albinsson, P.A.; Perera, B.Y. Alternative marketplaces in the 21st century: Building community through sharing events. J. Consum. Behav. 2012, 11, 303-315. [CrossRef]

45. John, N.A. The Social Logics of Sharing. Commun. Rev. 2013, 16, 113-131. [CrossRef]

46. Rousseau, D.M.; Sitkin, S.B.; Burt, R.S.; Camerer, C. Not So Different After All: A Cross-Disipline View of Trust. Acad. Manag. J. 1998, 3, 393-404. [CrossRef]

47. Giddens, A. Living in a Post-Traditional Society; Polity Press: Cabridge, UK, 1994; pp. 56-109.

48. Fukuyama, F. Trust. The Social Virtues and the Creation of Prosperity; Free Press: New York, NY, USA, 1995.

49. Uslaner, E. Trust as a Moral Value. In Handbook of Social Capital; Castiglione, D., van Deth, J.W., Wolleb, G., Eds.; Oxford University Press: Oxford, UK, 2006.

50. Putnam, R. Bowling Alone: The Collapse and Revival of American Community; Simon Schuster: New York, NY, USA, 2000.

51. Inglehardt, R.; Weltzel, C. Modernization, Cultural Change, and Democracy. The Human Development Sequence; Cambridge University Press: Cambridge, UK, 2005.

52. Edelman. Trust Barometer. Executive Summary. Available online: https://www.edelman.com/sites/g/files/aatuss191/files/20 1902/2019_Edelman_Trust_Barometer_Executive_Summary.pdf (accessed on 4 April 2021).

53. Pennington, R.; Wilcox, H.D.; Grover, V. The Role of System Trust in Business-to-Consumer Transactions. J. Manag. Inf. Syst. 2003, 20, 197-226. [CrossRef]

54. Ostrom, E. Governing the Commons: The Evolution of Institutions for Collective Action; Cambridge University Press: Cambridge, UK, 1990.

55. Cox, J.C.; Ostrom, E.; Walker, M.; Castillo, A.J. Trust in private and common property experiments. South. Econ. J. 2009, 75, 957-975.

56. Jarvenpaa, S.L.; Leidner, D.E. Communication and Trust in Global Virtual Teams. Organ. Sci. 1999, 10, 791-815. [CrossRef]

57. Meyerson, D.; Weick, K.E.; Kramer, R.M. Swift Trust and Temporary Groups. In Trust in Organizations: Frontiers of Theory and Research; SAGE Business Cases Originals; SAGE Publications: Newcastle upon Tyne, UK, 2012; pp. $166-195$.

58. Botsman, R. Who Can You Trust? How Technology Brought Us Together-And Why It Could Drive Us Apart; Penguin Random House: London, UK, 2017.

59. Sun, J.; Yan, J.; Zhang, K.Z.K. Blockchain-based sharing services: What blockchain technology can contribute to smart cities. Financ. Innov. 2016, 2, 26. [CrossRef]

60. Hawlitschek, F.; Notheisen, B.; Teubner, T. The limits of trust-free systems: A literature review on blockchain technology and trust in the sharing economy. Electron. Commer. Res. Appl. 2018, 29, 50-63. [CrossRef]

61. Golightly, D.; Houghton, R.; Hughes, N.; Sharples, S. Human Factors in Exclusive and Shared Use in the UK Transport System; Government Office for Science: London, UK, 2019.

62. Lovejoy, K.; Handy, S. Social networks as a source of private-vehicle transportation: The practice of getting rides and borrowing vehicles among Mexican immigrants in California. Transp. Res. Part A Policy Pract. 2011, 45, 248-257. [CrossRef]

63. Hartl, B.; Hofmann, E.; Kirchler, E. Do we need rules for "what's mine is yours"? Governance in collaborative consumption communities. J. Bus. Res. 2016, 69, 2756-2763. [CrossRef]

64. Krawchenko, T. Social Trust: An Invisible Glue for Better Urban Planning. Available online: http://oecdinsights.org/2018/03/12 / social-trust-an-invisible-glue-for-better-urban-planning/ (accessed on 14 December 2019).

65. Priya Uteng, T.; Julsrud, T.E.; George, C. The role of life events and context in type of car share uptake: Comparing users of peer-to-peer and cooperative programs in Oslo, Norway. Transp. Res. Part D Transp. Environ. 2019, 71, 186-206. [CrossRef]

66. Delhey, J.; Weltzel, C. Generalizing Trust. How Outgroup-Trust Grows Beyond Ingroup-Trust. World Values Res. 2012, 5, 46-69. [CrossRef]

67. Clarke, K.; Gillian, H.; Nark, R. Trust in Technology: A Socio-Technical Perspective; Springer: Dortdrecht, The Netherlands, 2006. 
68. Johnson, D.S.; Bardhi, F.; Dunn, D.T. Understanding how technology paradoxes affect customer satisfaction with self-service technology: The role of performance ambiguity and trust in technology. Psychol. Mark. 2008, 25, 416-443. [CrossRef]

69. McKnight, D.H.; Carter, M.; Thatcher, J.B.; Clay, P.F. Trust in a Specific Technology: An Investigation of Its Components and Measures. ACM Trans. Manag. Inf. 2011, 2, 12. [CrossRef]

70. Julsrud, T.E.; Krogstad, J.R. Is there enough trust for the smart city? exploring acceptance for use of mobile phone data in oslo and tallinn. Technol. Forecast. Soc. Chang. 2020, 161, 120314. [CrossRef]

71. Hinton, P.; McMurray, I.; Brownlow, C. SPSS Explained; Routledge: London, UK, 2004.

72. Briggs, S.R.; Cheek, J.M. The role of factor analysis in development and evaluation of personality scales. J. Personal. 1986, 54, 106-148. [CrossRef]

73. Dill, J.; Mcneil, N.; Howland, S. Effects of peer-to-peer car sharing on vehicle owners' travel behavior. Transp. Res. Part C. 2018, 101, 70-78. [CrossRef]

74. Blau, P. Interaction: Social Exchange. In International Encyclopedia of the Social Sciences; Sills, D.L., Ed.; Macmillian: New York, NY, USA, 1968; pp. 452-458.

75. Lewicki, R.L.; Bunker, B.B. Developing and Maintaining Trust in Work Relationships. In Trust in Organizations. Frontiers of Theory and Research; Kramer, R., Tyler, T., Eds.; Sage: Thousand Oaks, CA, USA, 1996; pp. 114-139.

76. Ozanne, L.K.; Ballantine, P.W. Sharing as a form of anti-consumption? An examination of toy library users. J. Consum. Behav. 2010, 9, 485-498. [CrossRef]

77. Coleman, J.S. Social Capital in the Creation of Human Capital. Netw. Knowl. Econ. 2003, 1988, 95-120.

78. Westskog, H.; Winther, T.; Strumse, E.; Galarraga, I.; González-Eguino, M.; Markandya, A. Addressing Fields of Rationality: A Policy for Reducing Household Energy Consumption? In Handbook of Sustainable Energy; Edward Elgar Publishing: Cheltenham, UK, 2013.

79. Julsrud, T.E. Flows, bridges and brokers: Exploring the development of trust relations in a distributed work group. Int. J. Netw. Virtual Organ. 2008, 5, 83. [CrossRef]

80. Andreasson, U. Trust-The Nordic Gold; Nordic Council of Ministers: Copenhagen, Denmark, 2017; p. 23. 